PENELITIAN

\title{
Pengaruh Asam Traneksamat pada Profil Koagulasi Pasien yang Mendapatkan Ketorolak
}

\section{The Effect Of Tranexamic Acid on Coagulation Profile of Patients Receiving Ketorolac}

\author{
Hijrineli $\bigotimes_{*}^{*}$,Soenarjo**, Mohamad Sofyan Harahap** \\ *Bagian Anestesiologi dan Terapi Intensif RSUD Mataram, \\ **Bagian Anestesiologi dan Terapi Intensif FK Undip/ RSUP dr. Kariadi, Semarang \\ \Korespondensi/correspondence: hijrie_dr@yahoo.co.id
}

\begin{abstract}
Background: Intra-operative bleeding is one of the challenges in anesthesia. Management of bleeding is an important modality for the anesthesiologist to maintain the patient in a state of physiological homeostasis. Ketorolac is a nonsteroidal antiinflammatory drugs (NSAIDs) are often used as intraoperative and postoperative analgesia in surgical patients. NSAID use as a post-surgical analgesia has side effects such as interference with the function of hemostasis, is one of its manifestations extended bleeding time. Tranexamic acid can reduce the amount of bleeding and save the use of coagulation factors durante operations, and thus is expected to improve the coagulation profile (PPT and aPTT) of patients who received ketorolac.
\end{abstract}

Objectives: To investigate the effect of Tranexamic acid administration to PPT and aPTT in patients given ketorolac

Method: This study is a clinical experimental study with randomized controlled blind design in Central Operating Theatre of Kariadi Hospital Semarang. Sample was taken from patient using simple random sampling and divided into two group. The first group (KI) was administered ketorolac and tranexamic acid .Second group (K II) was given ketorolac and placebo. Statistical analysis was performed with SPSS 16 for Windows.

Result: Preoperatively, PPT between groups were not significantly different (KI : $12.27 \pm 0.811 ; K$ II: $12.89 \pm 1.041 ; p: 0.083)$, and so were preoperative aPTT (K I: $30.01 \pm 2.060$; K II: $31.43 \pm 3.632$; p: 0.196). In 2 hours post operative PPT were prolonged in both groups but were not significantly different between groups ( $K I$ :

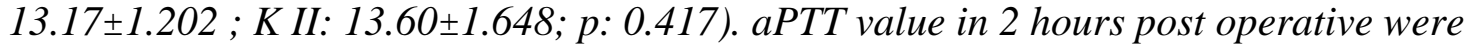

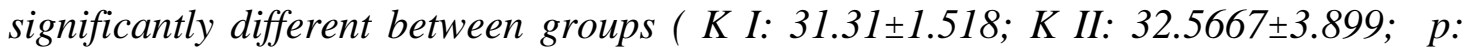
0.007). In 6 hours post operative, PPT K I were shortened ( $12.43 \pm 0.8314)$, but K II were still prolonged $(13.793 \pm 1.384 ; \quad p: 0.003) . \quad$ In aPTT, $K$ I shortened

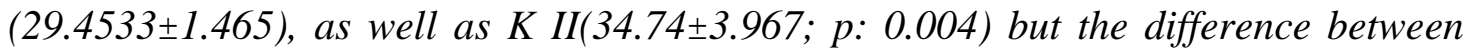
groups were significant.

Conclusion: Statistically, Tranexamic acid administration provide significant improvement the coagulation profile in patients given ketorolac.

Keywords : Ketorolac, Tranexamic acid, PPT, aPTT 


\section{ABSTRAK}

Latar Belakang: Perdarahan intra operatif adalah salah satu tantangan dalam bidang anestesi. Penanganan perdarahan merupakan modalitas yang penting bagi ahli anestesi untuk mempertahankan keadaan pasien dalam homeostasis fisologis

Ketorolak adalah obat antiinflamasi nonsteroid (OAINS) yang sering digunakan sebagai analgesia intraoperatif maupun post operatif pada pasien bedah. Penggunaan OAINS sebagai analgesia paska bedah memiliki efek samping berupa gangguan pada fungsi hemostasis, salah satu manifestasinya adalah memperpanjang waktu perdarahan. Asam traneksamat dapat menurunkan jumlah perdarahan dan menghemat pemakaian faktor faktor koagulasi durante operasi, dan demikian diharapkan akan memperbaiki profil koagulasi (PPT dan aPTT)pasien yang mendapatkan ketorolak.

Tujuan: Mengetahui pengaruh pemberian asam traneksamat terhadap PPT dan aPTT pasien yang mendapatkan ketorolak

Metode: Penelitian ini merupakan uji eksperimental klinis dengan desain acak tersamar di Instalasi Bedah Sentral (IBS) RSUP Dr. Kariadi Semarang. Sampel diambil dari pasien yang menjalani operasi menggunakan "simple random sampling" dan dibagi menjadi dua kelompok : Kelompok 1 (K1) diberikan diberikan ketorolak 30 $m g$ iv dan Asam traneksamat 1 gram intravena; Kelompok 2 (K2) diberikan diberikan ketorolak $30 \mathrm{mg}$ iv dan placebo. Pasien dinilai PPT dan aPTT sebelum operasi, 2 jam pasca operasi dan 6 jam pasca operasi. Analisis statistik dengan SPSS for Windows versi 16.

Hasil: Pada periode pre operatif, rerata PPT kedua kelompok cenderung tidak berbeda bermakna (KI : 12.27 \pm 0.811 detik $; K$ II: $12.89 \pm 1.041 ; p: 0.083)$, demikian pula aPTT pre operatif (K I: $30.01 \pm 2.060$ detik; K II: $31.43 \pm 3.632$; p: 0.196). Pada 2 jam post operatif terjadi pemanjangan PPT pada kedua kelompok namun beda kedua

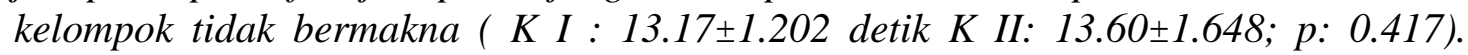
Perbedaan nilai aPTT 2 jam pasca operasi kedua kelompok tersebut bermakna secara

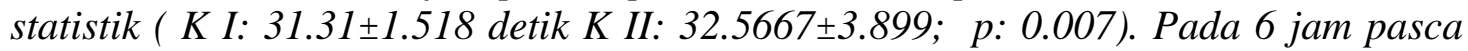
operasi, PPT K I memendek ( $12.43 \pm 0.8314)$, namun $K$ II tetap memanjang

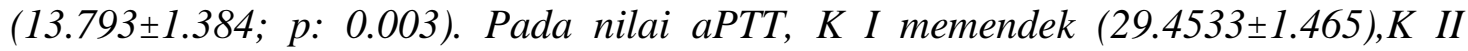
(34.74 $\pm 3.967 ; p: 0.004)$.

Simpulan: Pemberian asam traneksamat dapat memperbaiki studi koagulasi pasien yang mendapatkan ketorolak secara bermakna secara statistik

Kata Kunci: Ketorolak, Asam traneksamat, PPT, aPTT

\section{PENDAHULUAN}

Perdarahan intra operatif adalah salah satu tantangan dalam bidang anestesi. Perdarahan merupakan salah satu komplikasi dari operasi. Penanganan perdarahan merupakan modalitas yang penting bagi ahli anestesi untuk mempertahankan keadaan pasien dalam homeostasis fisologis ${ }^{1}$ 
Asam traneksamat adalah obat yang sering digunakan dalam menangani perdarahan intra dan pasca operasi. Asam traneksamat bekerja sebagai anti fibrinolitik dengan menghambat pemecahan fibrin polimer oleh plasmin, sehingga hemostasis dapat terjadi dengan lebih efektif. ${ }^{2}$ Sebuah penelitian metaanalisis menyatakan bahwa asam traneksamat dapat menurunkan jumlah perdarahan dan menghemat pemakaian faktor faktor koagulasi durante operasi. ${ }^{3}$ Myles menyatakan bahwa asam traneksamat mengurangi jumlah perdarahan secara bermakna pada pasien bedah koroner yang mendapatkan aspirin ${ }^{4}$

Ketorolak adalah obat antiinflamasi nonsteroid (OAINS) parenteral yang sering digunakan sebagai analgesia intraoperatif maupun post operatif pada pasien bedah. ${ }^{1,2}$ Penggunaan OAINS sebagai analgesia paska bedah memiliki efek samping berupa gangguan pada fungsi hemostasis, salah satu manifestasinya adalah memperpanjang waktu perdarahan. Pada penelitian Hendrasto et al, pemberian ketorolak 30 mg IV pada penderita dengan anestesi spinal tidak berpengaruh terhadap fungsi koagulasi jalur ekstrinsik (PT) tapi akan memperpanjang fungsi koagulasi jalur intrinsik (PTT) namun pemanjangan ini masih dalam batas normal atau tidak nampak secara klinis. $^{5}$ Masih terdapat kontroversi mengenai pengaruh ketorolak terhadap perdarahan. Berdasarkan penelitian Soenarjo et al tidak terjadi pemanjangan waktu perdarahan yang bermakna pada penderita pasca tonsilektomi yang mendapatkan ketorolak dibandingkan pasien yang mendapatkan analgetik opioid. ${ }^{6}$

\section{METODE}

Penelitian ini berbentuk "Randomized Clinical Controlled Trial" yang dilakukan di Instalansi Bedah Sentral RSUP Dr. Kariadi Semarang bulan Januari sampai April 2013.

Seleksi penderita dilakukan saat kunjungan prabedah di RSUP. Dr. Kariadi Semarang pada pasien yang akan menjalani operasi elektif dengan anestesi umum

Pasien diikutsertakan dalam penelitian apabila berusia antara 16 - 65 tahun, status fisik ASA I-II, menjalani operasi ortopedi, BMI 18-23 kg/m2, kadar trombosit lebih dari $100.000 / \mu \mathrm{L}$, tidak mengkonsumsi obat-obatan antikoagulan, dan sejenisnya, pasien tidak memiliki riwayat hipertensi. Pasien dieksklusikan apabila lama operasi kurang dari 1 jam atau lebih dari 6 jam, didapatkan adverse effect pemakaian isoflurane, propofol, vecuronium, fentanyl, ketorolak dan asam traneksamat, mendapat HES lebih dari $20 \mathrm{cc} / \mathrm{kgBB} / \mathrm{hari}$ atau transfusi darah selama perlakuan (selama pemberian OAINS )

Pasien secara simple random dibagi menjadi 2 kelompok yaitu kelompok 1 ( K1) diberikan ketorolak $30 \mathrm{mg}$ iv dan asam traneksamat 1 gram intravena dan 
kelompok 2 ( K2) diberikan ketorolak $30 \mathrm{mg}$ iv dan placebo. Semua pasien dipuasakan 6 jam sebelum operasi, kebutuhan cairan selama puasa dipenuhi sebelum operasi dengan menggunakan ringer laktat.

PPT dan aPTT diperiksa dengan reagen PTT dan Kaolin dan dilakukan sesuai di laboratorium sentral RSUP Dr. Kariadi. Pemeriksaan pra-perlakuan dilakukan pada sampel darah yang diambil dari vena mediana cubiti sebelum subjek mulai dipuasakan. Pada saat induksi subjek mendapatkan perlakuan OAINS ketorolak, dan mendapat asam traneksamat atau plasebo sesuai kelompok perlakuan. Saat induksi semua pasien disedasi dengan propofol $2 \mathrm{mg} / \mathrm{kgBB}$, setelah reflek bulu mata hilang diberikan vecuronium bromida 0,1 $\mathrm{mg} / \mathrm{kgBB}$, kemudian dilakukan intubasi endotrakea. Untuk rumatan anestesi pada kedua kelompok mendapat perlakuan sama, menggunakan isoflurane $0,8-1,2$ vol \% , $\mathrm{N} 2 \mathrm{O} 50 \%$ dan $\mathrm{O} 250 \%$ sampai operasi berakhir. Kedua kelompok dapat diberikan penambahan obat pelumpuh otot vecuronium bromida $0,05 \mathrm{mg} / \mathrm{kgBB}$ bila diperlukan dan pemberian fentanyl sebagai analgetik intravena rumatan. Dua jam dan 6 jam setelah perlakuan, pasien kembali diperiksa PPT dan aPTT ulang dengan sampel dari vena mediana cubiti.

Data yang didapatkan diuji secara statistik dengan SPSS for Windows versi 16.

\section{HASIL}

Sebanyak tiga puluh pasien masuk dalam kriteria inklusi dalam sampel penelitian. Pasien dikelompokkan dalam kelompok ketorolak dan asam traneksamat(I) sebanyak 15 pasien dan placebo(II) sebanyak 15 pasien. Tidak ada subjek dieksklusikan karena mengalami kejadian tak diharapkan.

Data dasar subjek diperlihatkan pada Tabel 1. Umur rerata kelompok I $32.20 \pm 14.239$ tahun, tidak berbeda bermakna dengan rerata umur kelompok II yaitu 30.13 \pm 13.506 ( $\mathrm{p}=0.771)$. Kelompok I terdiri dari 9 orang laki laki dan 6 orang perempuan., secara statistik berbeda tidak bermakna dengan kelompok II yaitu 11 orang laki - laki dan 4 orang perempuan $(p=0,104)$. Tidak dijumpai perbedaan bermakna untuk parameter umur, BMI, dan dan status ASA kedua kelompok sebelum pemberian tindakan. Terdapat perbedaan lama operasi yang secara statistik bermakna pada kedua kelompok yaitu 181.3 \pm 34.25 menit pada kelompok I dan $146.7 \pm 36.53$ menit pada kelompok II.

Pada periode pre operatif, rerata PPT dan aPTT kedua kelompok cenderung berbeda tidak bermakna (tabel 2). PPT pre operatif pada kelompok I adalah $12.27 \pm 0.811$ detik dan pada kelompok II 12.89 $\pm 1.041 . \quad(\mathrm{p}=0.083), \quad$ sedangkan aPTT pre operatif pada kelompok I adalah 30.01 \pm 2.060 detik dan pada kelompok II 31.43 \pm 3.632 ( $\mathrm{p}=0.196)$.

Pada 2 jam post operatif terjadi 
pemanjangan PPT dan aPTT pada kedua kelompok. PPT 2 jam pada kelompok I adalah 13.17 \pm 1.202 detik dan pada kelompok II 13.60 \pm 1.648 . Perbedaan PPT kedua kelompok secara statistik tidak bermakna. $(\mathrm{p}=0.417)$. Namun demikian aPTT 2 jam setelah perlakuan pada kelompok I adalah $31.31 \pm 1.518$ detik dan pada kelompok II 32.5667 \pm 3.899 . Perbedaan kedua nilai tersebut bermakna secara statistik $(\mathrm{p}=0.007)$

Pada 6 jam setelah perlakuan, PPT pada kelompok I memendek dibandingkan jam ke 2 dengan nilai 12.43 \pm 0.8314 , namun pada kelompok II, tetap mengalami pemanjangan dengan nilai 13.793 \pm 1.384 . Terdapat perbedaan bermakna nilai PPT kedua kelompok $(\mathrm{p}=0.003)$. Demikian pula pada nilai aPTT, pada kelompok I mengalami pemendekan dengan nilai $29.4533 \pm 1.465$, namun pada kelompok II, tetap mengalami pemanjangan dengan nilai 34.74 \pm 3.967 . Terdapat perbedaan bermakna nilai PPT kedua kelompok $(p=0.004)$.

Pada kelompok I dan II, terjadi pemanjangan PPT pada 2 jam setelah perlakuan, akan tetapi pada 6 jam setelah perlakuan PPT pada kelompok I cenderung kembali ke nilai awal, sedangkan pada kelompok II terus memanjang (gambar. 1). Perbedaan PPT pada kelompok I pada pre operatif dan 6 jam setelah perlakuan berbeda tidak bermakna secara statistik ( $\mathrm{p}=0.586$ ), namun perbedaan tersebut bermakna pada kelompok II ( $\mathrm{p}=0.017)$
Pada kelompok I dan II, terjadi pemanjangan aPTT pada 2 jam setelah perlakuan, akan tetapi pada 6 jam pasca operasi aPTT pada kelompok I menurun, bahkan lebih rendah dari nilai rerata awal, sedangkan pada kelompok II terus memanjang (gambar. 2). Perbedaan PPT pada kelompok I pada pre operatif dan 6 jam setelah perlakuan berbeda tidak bermakna secara statistik ( $\mathrm{p}=0.313$ ), namun perbedaan tersebut bermakna pada kelompok II $(\mathrm{p}=0.02)$

Batas normal PPT secara klinis adalah 10-15 detik, sedangkan aPTT 25 -35 detik. Meski pada penelitian ini didapatkan hasil yang bermakna secara statistik, namun hasil yang ditunjukkan pada keseluruhan waktu, baik pada kelompok I maupun kelompok II secara klinis masih dalam batas normal.

\section{PEMBAHASAN}

Hemostasis adalah proses fisiologis dalam tubuh untuk menghentikan perdarahan pada lesi vaskular. Komponen-komponen yang berperan dalam proses hemostasis yaitu pembuluh darah, trombosit, faktorfaktor pembekuan darah, protein antikoagulasi dan enzim fibrinolisis. Perubahan dalam keseimbangan antara aktivasi dan inhibisi pada sistem hemostasis akan menyebabkan kelainan berupa perdarahan atau trombosis. ${ }^{7}$

Ketorolak merupakan prototipikal obat antiinflamasi nonsteroid (OAINS) turunan asam proprionat yang memiliki efek atau aktivitas analgetik. Ketorolak 
telah digunakan sebagai pengobatan simptomatik terhadap nyeri postoperatif sedang, termasuk operasi pada abdomen, ginekologis, mulut, mata, ortopedik, urologis atau operasi otolaringologis. Sebagai tambahan, ketorolak dapat digunakan sebagai pengobatan pra operasi untuk meningkatkan anastesi, obat tidak mempunyai efek sedatif atau anxiolitik tetapi mungkin dapat menghambat agregasi platelet dan memperpanjang waktu pendarahan. ${ }^{8,9}$

Pada penelitian ini, pasien yang mendapatkan ketorolak sebagai analgetik menunjukkan adanya pemanjangan PPT dan aPTT. Pemanjangan tersebut terjadi hingga 6 jam setelah perlakuan. Meski demikian pemanjangan PPT dan aPTT tersebut berkisar $8 \%$ dari nilai awal, dan tidak bermakna secara klinis.

Penelitian terdahulu yang dilakukan oleh Singer et al menyimpulkan adanya peningkatan waktu perdarahan bermakna secara statistika pada pemberian ketorolak. $^{10}$ Sedangkan Istanto $\mathrm{W}$, et al melaporkan adanya perbedaan waktu perdarahan yang bermakna pada pasien yang medapatkan ketorolak $30 \mathrm{mg}$ IV dan ketoprofen $50 \mathrm{mg}$ IV. ${ }^{11}$ Peningkatan waktu perdarahan yang disebabkan oleh ketorolak mungkin dipengaruhi oleh berbagai faktor antara lain trombosit dan faktor pembekuan itu sendiri. Sulistiyowati menyatakan bahwa ketorolak mempengaruhi agregasi trombosit $^{12}$.
Penelitian ini menunjukkan bahwa ketorolak dapat mempengaruhi faktor pembekuan, baik dari jalur intrinsik, ekstrinsik dan jalur bersama. Hal tersebut tercermin dalam peningkatan nilai PPT dan aPTT. Meskipun demikian, pengaruh tersebut tidak cukup besar secara klinis. Hal tersebut ditunjukkan dengan nilai PPT dan aPTT yang masih dalam kisaran normal pada penelitian ini. Hal ini sejalan dengan hasil penelitian Soenarjo et al yang menunjukkan bahwa tidak terjadi pemanjangan waktu perdarahan yang bermakna pada penderita pasca tonsilektomi yang mendapatkan ketorolak dibandingkan pasien yang mendapatkan analgetik opioid. ${ }^{10}$. Meskipun gangguan koagulasi yang disebabkan oleh ketorolak tidak terlalu nyata secara klinis, namun temuan ini menunjukkan bahwa gangguan yang lebih nyata masih mungkin terjadi apabila ketorolak diberikan pada pasien yang telah mengalami gangguan kaskade koagulasi sebelum operasi. Pada perdarahan akibat operasi, seringkali terjadi pemakaian yang berlebihan dari faktor-faktor koagulasi. Hal tersebut tercermin dari pemanjangan studi koagulasi. Dengan dasar mekanisme hemostasis, dapat dipahami bahwa perdarahan yang berlebihan dapat terjadi karena adanya gangguan pada komponen yang berperan pada mekanisme tersebut, yaitu gangguan pembuluh darah, gangguan faktor-faktor pembekuan darah atau gangguan trombosit. 
Tabel 1. Karakteristik Awal Subyek Penelitian

\begin{tabular}{llll}
\hline Parameter & I & II & $\mathrm{p}^{*}$ \\
\hline $\begin{array}{l}\text { Jenis Kelamin } \\
\text { (L:P) }\end{array}$ & $9: 6$ & $11: 4$ & $0.104^{* *}$ \\
\hline Umur & $32.20 \pm 14.239$ & $30.13 \pm 13.506$ & $0.771^{* *}$ \\
\hline BMI & $20.20 \pm 1.424$ & $20.07 \pm 1.438$ & .800 \\
\hline ASA (I:II) & $11: 4$ & $14: 1$ & $.148^{* *}$ \\
\hline Lama operasi & $181.3 \pm 34.25$ & $146.7 \pm 36.53$ & .012 \\
\hline
\end{tabular}

* bermakna bila $\mathrm{p}<0.05 \quad * *$ Uji non parametric

Tabel 2. Beda Rerata PPT dan aPTT pada kedua kelompok

\begin{tabular}{cllllll}
\hline \multicolumn{2}{l}{ PPT } & \multicolumn{2}{l}{ aPTT } \\
\hline Kelompok & I & II & P* & I & II & P* \\
\hline Pre operatif & $12.27 \pm 0.811$ & $12.89 \pm 1.041$ & 0.083 & $30.01 \pm 2.060$ & $31.43 \pm 3.632$ & 0.196 \\
\hline 2 jam pasca op & $13.17 \pm 1.202$ & $13.60 \pm 1.648$ & 0.417 & $31.31 \pm 1.518$ & $32.5667 \pm 3.899$ & 0.007 \\
\hline 6 jam pasca op & $12.43 \pm 0.8314$ & $13.793 \pm 1.384$ & 0.003 & $29.45 \pm 1.465$ & $34.74 \pm 3.967$ & 0.004 \\
\hline
\end{tabular}

(*bermakna bila $\mathrm{p}<0.05$ )

Gambar 1. Perubahan PPT pada kedua kelompok

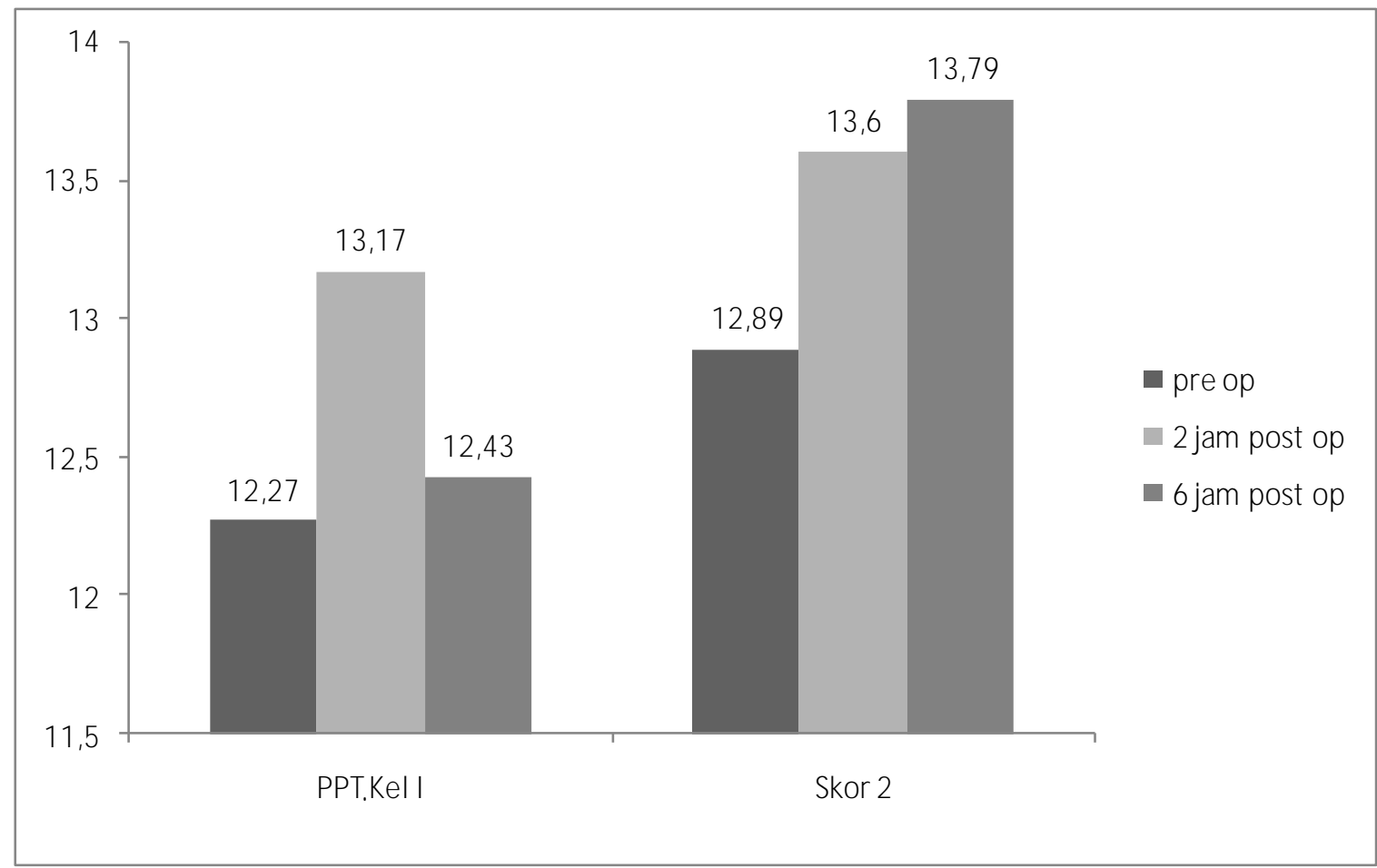


Gambar 2 Perubahan aPTT pada kedua kelompok

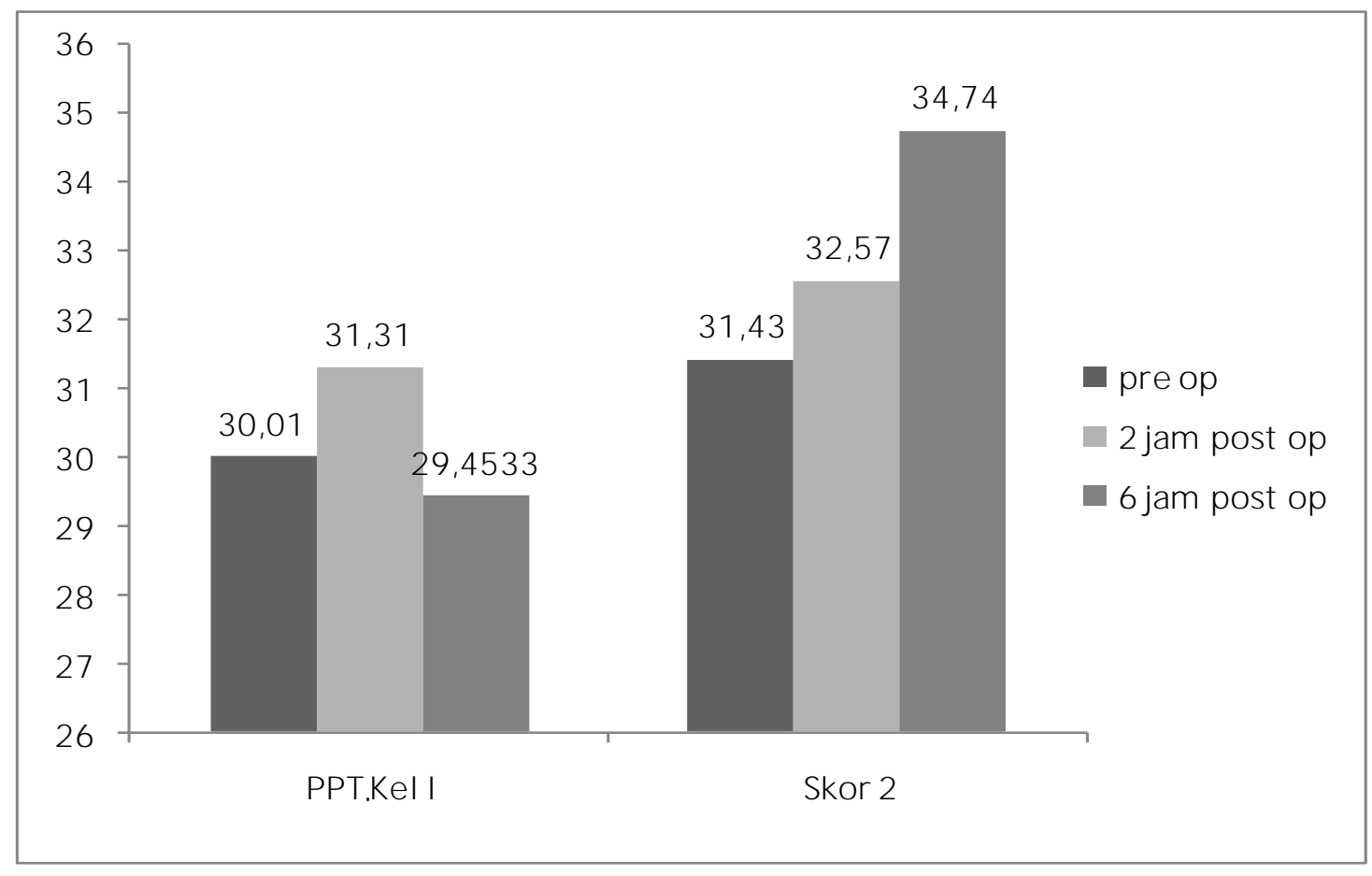

Ketorolak adalah obat antiinflamasi nonsteroid (OAINS) yang sudah digunakan sejak tahun 1990, ketorolak termasuk golongan OAINS yang bersifat nonselective inhibitor atau bersifat menghambat enzim COX-1 dan COX-2. Namun ketorolak memiliki aktivitas hambatan lebih besar terhadap enzim COX-1. Hambatan pada enzim COX-1 akan menyebabkan sintesis tromboksan A2 terhambat, yang merupakan salah satu faktor penting dalam agregasi trombosit dan pembekuan darah,sehingga dengan terhambatnya agregasi trombosit akan menyebabkan waktu perdarahan lebih panjang dan merupakan OAINS parenteral yang sering digunakan sebagai analgesia intraoperatif maupun post operatif pada pasien bedah. Penggunaan OAINS sebagai analgesia pasca bedah memiliki efek samping berupa gangguan pada fungsi hemostasis, salah satu manifestasinya adalah memperpanjang waktu perdarahan. ${ }^{1,2,11}$

Asam traneksamat salah adalah obat yang diharapkan dapat mengatasi efek gangguan koagulasi karena ketorolak dan OAINS lain. Penelitian terdahulu oleh Myles mendapatkan bahwa asam traneksamat mengurangi jumlah perdarahan secara bermakna pada pasien bedah koroner yang mendapatkan Aspirin. ${ }^{4}$ Asam traneksamat sering digunakan dalam menangani perdarahan intra dan pasca operasi. Asam traneksamat bekerja sebagai anti fibrinolitik dengan menghambat pemecahan fibrin polimer oleh plasmin, sehingga hemostasis dapat terjadi 
dengan lebih efektif. ${ }^{2}$ Penelitian Macgillivray menunjukkan bahwa Asam traneksamat mengurangi waktu perdarahan dan jumlah perdarahan pasien dengan artroplasti lutut secara bermakna $^{=13}$. Pada penelitian ini, pasien yang mendapatkan asam traneksamat dan ketorolak menunjukkan pemanjangan studi koagulasi yang lebih sedikit dibandingkan pasien yang mendapatkan ketorolak saja yang menunjukkan bermakna secara statistik.

Hal ini menunjukkan bahwa asam traneksamat dapat mengatasi efek ketorolak terhadap studi koagulasi, dan memperbaiki PPT dan aPTT pasien yang mendapatkan ketorolak.

PPT adalah pemeriksaan yang menggambarkan faktor koagulasi dari jalur ekstrinsik dan jalur bersama yaitu factor pembekuan VII, $\mathrm{X}, \mathrm{V}$, protrombin dan fibrinogen. Sedangkan aPTT adalah pemeriksaan yang menggambarkan faktor koagulasi dari jalur instrinsik dan jalur bersama yaitu factor pembekuan XII, prekalikrein, kininogen, factor pembekuan XI, IX, VIII, X, V, protombin dan fibrinogen. Dengan demikian, penggunaan asam traneksamat diduga dapat menghemat penggunaan faktor koagulasi baik dari jalur ekstrinsik, intrinsik dan jalur bersama. Temuan tersebut sejalan dengan pernyataan Kerr et al dalam metaanalisisnya bahwa asam traneksamat dapat menurunkan jumlah perdarahan dan menghemat pemakaian faktor - faktor koagulasi durante operasi. ${ }^{5}$ Meskipun demikian, pengaruh asam traneksamat yang tergambarkan pada peneitian ini berbeda tidak bermakna secara klinis.

Lama operasi pada kedua kelompok penelitian ini berbeda secara bermakna, namun demikian hal tersebut diperkirakan oleh peneliti tidak mempengaruhi penelitian. Perbedaan rerata waktu kedua kelompok adalah sebesar 60 menit, dimana pada kelompok I, lama operasi lebih panjang yaitu $181,3+34,25$ menit pada kelompok I dan 146.7+36.53 menit pada kelompok II. Pada kedua waktu tersebut, secara teoritis kedua obat yang dicobakan telah mencapai onset kerja dan masih dalam durasi kerjanya, demikian juga 2 jam dan 6 jam setelah perlakuan. Penurunan atau peningkatan kadar plasma kedua obat, juga secara farmakologi belum terjadi. $^{2}$

Lama operasi tidak mempengaruhi penggunaan factor koagulasi secara bermakna, bahkan pada operasi mayor. Hal ini menyebabkan lama operasi dapat dianggap tidak mempegaruhi studi koagulasi pada penelitian ini. Pada penelitian ini juga didapatkan bahwa pada kelompok yang diberikan asama traneksamat, meskipun mengalami durasi operasi yang lebih panjang, namun memiliki hasil studi koagulasi yang lebih pendek.

Pada penelitian ini tidak didapatkan efek samping yang serius pada penggunaan kedua obat yang dicobakan. Demikian pula, secara klinis, tidak didapatkan kejadian trombosis vena ataupun arteri 
pada pasien yang mendapatkan asam traneksamat.

\section{SIMPULAN}

Pemberian ketorolak $30 \quad \mathrm{mg} \quad$ IV menyebabkan pemanjangan PPT dan aPTT yang bermakna secara statistik pada pasien pada 2 jam dan 6 jam setelah perlakuan. Pemberian asam traneksamat 1 gram menyebabkan pemanjangan PPT dan aPTT pasien yang mendapat ketorolak lebih kecil pada 2 jam setelah perlakuan. Pemberian asam traneksamat menyebabkan PPT dan aPTT pasien yang mendapat ketorolak kembali mendekati nilai awal pada 6 jam setelah perlakuan. Terdapat perbedaan yang bermakna secara statistik pada nilai PPT dan aPTT 2 jam dan 6 jam setelah perlakuan yang mendapatkan asam traneksamat dan ketorolak dengan pasien yang mendapatkan ketorolak saja. Secara klinis perbedaan tersebut berbeda tidak bermakna.

\section{DAFTAR PUSTAKA}

1. Rutherford E, Skeete D, et al. Hematologic principles in surgery. In:Sabiston textbook of surgery. 17th edition. Philadelphia: Elvesier Saunders; 2004. p. 125

2. Stoelting RK, Hillier SC. Blood components, substitutes, and hemostatic drugs. In: Pharmacology and Physiology in Anesthetic Practice. 4th ed. Philadelphia: Lippincott Williams \& Wilkins; 2006.p.623-634

3. 5 Roberts I, Perrel P, Merino DP. Effect of tranexamic acid on mortality in patients with traumatic bleeding: prespecified analysis of data from randomised controlled trial. BMJ 2012; 345
4. Myles PS, Smith J, Knight J, Cooper DJ, Silbert B, McNeil J, et al. Aspirin and Tranexamic Acid for Coronary Artery Surgery (ATACAS) Trial: rationale and design. Am Heart J. 2008;155(2):224-30

5. Hendrasto A, Arifin J, Harahap MS. Pengaruh Pemberian Ketorolak $30 \mathrm{mg}$ Intravena pada Penderita dengan Anestesi Spinal Terhadap Fungsi Pembekuan Darah : Protrombin Time, Partial Tromboplastin Time with Kaolin.Jurnal Anestesiologi Indonesia 2009; 1(1): 26-31

6. Soenarjo, Lian A, Meriwijanti. Evaluasi efek analgetik ketoprofen dan ketorolak intravena pasca tonsilektomi. Majalah Kedokteran Indonesia 2004; 54 (9): 378-82

7. Oesman F, Setiabudy RD. Fisiologi hemostasis dan fibrinolisis. Dalam: Setiabudy RD, editor. Hemostasis dan trombosis. Edisi ketiga. Jakarta: Balai Penerbit FKUI; 2007. hal.1-15

8. Ketorolac Drug Information [cited 2012 Jul 3] . Available from : http://www.drugs. com/MTM/ ketorolac.html

9. Lee SY, Lee WH, Lee EH, Han KC, Ko YK. The effects of paracetamol, ketorolac, and paracetamol plus morphine on pain control after thyroidectomy. Korean J Pain. 2010 ;23 (2):124-30

10. Singer AJ, Mynster CJ, McMahon BJ. The effect of IM ketorolac tromethamine on bleeding time. The New England Journal of Medicine 2003; 21(5): 441-3

11. Istanto W, Setyono KC. Pengaruh ketorolak intravena dan deksketoprofen intravena sebagai analgesia pascabedah terhadap waktu perdarahan [tesis]. Semarang: Universitas Diponegoro; 2009

12.8 Sulistiyowati R. Perbedaan pengaruh pemberian ketorolak dan deksketoprofen sebagai analgesia pasca bedah terhadap agregasi trombosit [tesis]. Semarang: Universitas Diponegoro; 2009

13. MacGillivray RG, Tarabichi SB, Hawari MF, Raoof NT.Tranexamic acid to reduce blood loss after bilateral total knee arthroplasty: a prospective, randomized double blind study. J Arthroplasty. 2011 ;26(1):24-8 